\title{
Social Responsibility and Its Effect on the Companies' Success According to Users Opinions in Jordan
}

\author{
Raed Kanakriyah ${ }^{1}$ \\ ${ }^{1}$ Accounting Department, Faculty of Business, Al-Balqa’ Applied University, Al-Salt, Jordan \\ Correspondence: Raed Kanakriyah, Accounting Department, Faculty of Business, Al-Balqa’ Applied University, \\ Al-Salt, P.O. Box: Al-Salt 19117, Jordan. Tel: 962-5-349-1111. E-mail: raedkkk1967@yahoo.com or \\ kraed71@bau.edu.com
}

Received: October 12, 2016

Accepted: October 24, 2016

Online Published: November 20, 2016

doi:10.5539/ijef.v8n12p187

URL: http://dx.doi.org/10.5539/ijef.v8n12p187

\begin{abstract}
The main purpose of this study is to examine the impact of social responsibility on the companies' success according to users' opinions, the study applies the qualitative method to collect the data through semi-structure interview to extract the users perception about how social responsibility effect on companies' success, the researcher identified several criteria to understand the concept of "social responsibility" and used several variables (ten variable) as a proxy to measure companies' success, the paper indicate that all accounting information users agree on the importance of social responsibility to help them in the judging the companies' success and there is a strong effect of social responsibility on the companies' success which in turn affect users' decisions, such as investors. The public image of the organization will be better when playing a social role, and reduce the government's actions and laws, one of the most important results obtained from the respondents' views is that CSR announcements provide new information to the market and allow the users to change or modify their decisions, also we find that two groups' investors and accountants have a very diverse view on CSR application. The findings of the study have important implications concerning users of financial statements. In particular, investors and creditors (the supplier of capital) the study confirms that the importance of social responsibility and the main role of social responsibility in decision making process. It is believed that there is no Jordanian study to date examining the impact of the social responsibility on the companies' success according users perspective. Also this considers the first study that used the qualitative method for data collection semi-structure interview, therefore, this study significantly contributes to the limited literature on the perceived the effect of social responsibility on the firm's success. The difficulty of applying such studies depending on interviewing in developing countries, such as Jordan.
\end{abstract}

Keywords: social responsibility, companies' success, quality of accounting information, firms profitability, accounting information users, Jordan

\section{Introduction}

The main goal for all firms is to provide value and create profit for shareholders, whereas companies also focus on how the surrounding environments accept their activities, so most company's aims to support charitable activities, implement positive activities that governments should undertake, even they are not accountable to applied or submit such activities, so company's should take in their consideration the impacts of its choices and activities on its environment and society, during transparent and ethical activities that improves sustainable development, involve the health and welfare of society; takes into account the stakeholders interests and goals; and must be in compliance with appropriate law and consistent with international standards of behaviour and practised in all company activities and its relations.

The role of the private sector has become essential in the development process, as evidenced by the successes achieved within advanced economies in world. they realized the important role of private sector that can't isolated from society, who became a strategic partner for government and became aware of the need to expand its activities to include necessary activities for its environment, and these companies need to take into account three important elements that defined by the world business council: economic growth, social progress and environmental protection, which consider as a comprehensive view on corporate responsibility, it will be important to examine its influence on how companies recognize, design and manage this aspect of their business 
operations.

Currently no longer evaluate companies depends only on profitability or its financial position, but also based on how environments accepted their activities, this study emphasize directly on the importance of applying companies for social responsibility and its influences on the economic, social and environmental that resulted from their business, for all these reasons, this study came to reveal and understand the impact of the social responsibility application on the company's success, which is the core of the study, because become clear that the application of the concept of social responsibility provides companies a competitive advantage, and it is a strong indicator of company's responsibility to its environment, which will reflect positively on the company's business, increased its acceptance. according to the researcher knowledge, there is no any study, aims to discover such relationship in developed countries, and in developing countries such as Jordan, which gave great importance to the results of this study.

\subsection{Problem of the Study}

The success of any corporate depends on its successful and acceptance internally and externally, the success of applying social responsibility based mainly on commitment to three criteria: the first criteria, respect and responsibility; how the company respect internal environment such as (workers or employees) and the external environment such as (community members). The second criteria, community support; how the company's support its environment by applying new activities. while the third criteria, protection of the environment; in terms of companies commitment about its product offered to the community and environment, or in terms of initiative that aims to improve environmental conditions in the community and to address various environmental problems, for these reasons this study came to discover the extent to which the companies in Jordan achieved a successful social responsibility and discovering its impact on companies' success according to users opinion.

\subsection{Importance of the Study}

Sharma et al. (2009) indicate any firm aims to achieve high success by enhanced profitability, employees' confidence, customer satisfaction, legal conformity and societal approval for its survival, but doing these improvements depends on applying the new management concept corporate social responsibility and how its affect on companies profitability. The main idea of the study was to recognize and achieve deeper understand for factors that encourage or thwart success of CSR implementation and to ensure accurate results and recommendations enabling discover tools that will assist, strengthen and expand CSR impact in the company's success.

the importance of this study Stems from the necessity of measuring the extent to which the application of CSR is affected on firms success in Jordan, according to researcher knowledge its consider the first study aims to measure the influence of CSR according to users perspective and this study differentiate from others or previous studies by its methodology that applied, (Semi- structured interviews) which will enrich and provide reliable information, the most important is how to improve mental image among the organization stakeholders, whether they are internal audiences such as employees and shareholders or external audiences such as customers and creditors. The researcher applied a scientific method to understand this phenomenon which known as descriptive and analytical approach, by applying interviews to collect valuable data, help in describe and understand this phenomenon, in addition to achieve an accurate description and familiarity with all aspects of it, and analyzed information to reach a generalizable results.

The concept of corporate social responsibility is considered one of the modern concepts, but as mentioned previous. Until yet, there is no consensus agreement for CSR definition, despite the simplicity of the theoretical essence, a harmony in institutions and actions among the community's expectations, and their reaction to the requirements of the legal and ethical values and with its environment. This study will contribute the literature by discovering the impact of CSR on gaining profit, achieve success and the relationship between CSR and management performance, through providing empirical evidence in different environment Middle East and Arabic countries.

Finally this study finding considered a significant implication for enhancement of CSR in Jordan, and to improve CSR mechanisms. They may also be important to both the professional environment and regulators. On the other hand, the Jordan government encourages CSR research by holding symposiums, adopting modern research and attracting expertise that will play a vital role in developing CSR mechanisms. Companies in Jordan have a general understanding of the important of the CSR concept and developed a holistic and mature use regarding the development and implementation of it. Actually, a current study aims to bridging the gap which still found in Jordan about the reality that Jordan still have a lengthy way to go towards CSR in their business practices, and how it's important for increase its profit market share. 


\subsection{Theoretical Framework of the Study}

A theoretical framework was used in current study based on stakeholders theory, which interpreting the success of the organization that will serve as the function or process to the extent to which it can whereby satisfy the needs of different stakeholders and balance accurately (fairly) and without sacrificing one's from others.

According to (Donaldson \& Preston, 1995) stated that stakeholder theory emphasize the importance of CSR on companies performance or financial performance (FP) because it increased the satisfaction of all stakeholders, therefore the firm's enrich its reputation which will lead to better financial performance. This is entirely consistent with (Freeman \& Evan, 1990; Orlitsky et al., 2003) whom found that managers usually enhance the efficiency of their companies' adaptation to external demands through dealing and balancing the claims of different stakeholders, on the contrary, Cornell and Shapiro (1987) discuss if the company doesn't achieve the expectations of stakeholders which will create market fears, therefore, will increase company risk and finally decrease its opportunities for more profit. Depending on that, the study stemmed on this theoretical.

\section{Literature Review}

\subsection{Emergence Social Responsibility: The Historical Development of CSR}

1) First phase; Maximizing Profits Phase (1800-1920)

At this stage, the primary responsibility of company is to maximize profits and the trend towards pure self-interest, and raise the logo of "what is good for me is good for the country"

2) Second phase; Trusteeship management phase, from (1921-1960)

During this period, the core business responsibility is to achieve an appropriate profit that achieves self-interest and the interests of other parties (stakeholders) such as shareholders and employees, and the logo during this period is "what is good for companies is good for the country".

\section{3) Third phase; Stage management quality of life (1961- until know)}

Profit is essential but the primary responsibility for companies (firms) is to discovering society and customer wants, need and how satisfy them, individuals more important than money, and this is the best interest for the company, interests of shareholders and society as a whole, the logo in this phase is "what is good for society is good for the country, and this known as corporate social responsibility

From the literature survey, it appears that most studies focused on three pivotal aspects relating to CSR, the first investigate the effect of applying corporate social responsibility on the companies' performance (financial performance), and increase clearness through increasing the reliability of accounting information (Suwaidan et al., 2004; Alkhater \& Naser, 2003; Weshah et al., 2012; Rasoulzadeh et al., 2013; Dahlsrud, 2006; Lakshmi Das, \& Amalendu Bhunia, 2016; Gbadamosi, 2016). The second pivot measure the effect of CSR on profitability (Hatfield, 1985; Abbott \& Monsen, 1979; Carlsson \& Akerstom, 2008; D. J. Wood, 2010; Alkhalaileh \& Abu Farha, 2016). The third pivot examines the feedback or reaction of the market to CSR (market reaction), (Smith \& Alcom, 1991; Adeyanju, 2012; Baker, 2010; Payne \& Raiborn, 2002; Cajias et al., 2014).

About the first pivot, there are no enough studies in the accounting literature that examine the effect of CSR on improving financial performance in middle east ; this is considered one of important reasons for applying this study, mainly in developing countries, the first pivot examined the effects of corporate social responsibility on the companies' performance, and most studies used the traditional variable such as ROE, ROA, Sales growth, market returns to evaluate financial performance (Wu \& Shen, 2013). There is a important relation between corporate social responsibility (CSR) and firm performance has been tested by many researcher, For example Suwaidan et al. (2004) assess the corporate social responsibility practices through manufacturing companies in Jordan, they found important need for additional disclosures about social responsibility, and also Alkhater and Naser (2003) examined users' perception regarding corporate social responsibility in Qatar, their outcome show that users strongly support the companies to announcement CSR information in their financial report while Margaretha and Rachmawati (2016) find that CSR has no significant effect on the companies' financial performance. But also they detect environment has an important effect on ROA, from other hand Rizk et al. (2008) discovered a significant differences in practices between different sectors regarding CSR and these practices are significantly influenced by the ownership structure in corporations, also Weshah et al. (2012) find a significant relationship between social responsibility and financial performance and emphasize the importance of adopting social responsibility, the same result achieved by (Lakshmi \& Amalendu, 2016; Mahtab, 2015; Mujahid \& Abdullah, 2014; Malik \& Nadeem, 2014). However, Dahlsrud (2006) define five dimensions for corporate social responsibility that effect on the firms successful, the first dimension is the environmental dimension which 
relate to natural environment, the second is the social dimension explain the relationship between firms and its society the third is the economic dimension relates to Socio-economic, financial aspects, that mentioned the factors of CSR which relate to firms activities, the fourth is the stakeholder dimension which discuss how satisfy all parties relates to the firms( stakeholder groups) the fifth is the voluntariness dimension associated to any actions not required by the law. In the Jordanian context, Also firms should define the organizational performance.

Also, Chung Hee KIM (2013) discovered that CSR's has impact on employee motivation Devinney et al. (2005) define three specific areas to measures organizational performance the first is Financial performance (net profits, return on assets ROE and ROI return on investment, or return on assets, the second is Market performance (sales, market share, competitive advantage; and the third Shareholder return.

While the second pivot examines the effect of CSR on profitability such as Cochran and Wood (1984), find a strong relation between financial position or performance and CSR, and emphasize the financial variable has most powerfully associated with CSR is asset age, the same result achieved by (Aupperle \& Hatfield, 1985), they discovered a strong correlation between social responsibility and profitability, Mcguire and Shneeweis (1988), they declare that CSR is considered the heart duty in firms because it interested with the relationship between the firm's social responsibility and their profitability. Sunghee Lee and Heungjun Jung (2016) their result indicate that the positive relationship between CSR and profitability depends on the levels of product differentiation and outside investment. Specifically, these contingent variables magnify the effects of CSR on financial performance. But Abbott and Monsen (1979) show conflicting results through their study, which indicate no certain proof for association between corporate social activities and profitability, consistent with Jensen et al. (2001) found that Corporate Social Responsibility is effect negatively on the financial performance and have negative impact on firm's performance and profitability.

Also Chin-Huang Lin et al. (2016) discovered a positive relationship between CSR and financial performance (Carlsson \& Akerstom, 2008; Das \& Bhunia, 2016) they found companies that applied CSR will improve financial performance, reputation and image of compound, and enhance a competitive advantage which will increase the profit. Gabriel et al. (2009) they find that companies that applied CSR are better performing rather than companies applied only QPS (Quality of products and services), BG (Effectiveness in doing business globally), IN (Innovativeness), CC (Corporate culture) and EO (Ethical obligations) in other words their result emphasize that firms implement CSR their result will be more strongly and more profitability, (Chung-Hua \& Yuan, 2009), examine the financial performance regarding to (CSR) and (NON-CSR), they find companies which applied CSR activities have good financial performance and profitability, the same result achieved by D. J. Wood, (2010), Conclusions emphasize the need for (CSP) to refocus on stakeholders and society, Alkhalaileh, and Abu Farha (2016) suggest that still Jordan need an empirical assessment of corporate social responsibility concept based on a strong infrastructure combined of both current practices and stakeholders' perception of corporate social responsibility concept is recommended, also they Alkhalaileh, and Abu Farha (2016) applied an empirical assessment of the relation between CSR and two variables, the first one is how the banks can achieve abnormal returns for investors if applied the CSR concepts, while the other variable relating the effect of disclosing greater in social responsibility activities on the firms profitability.

And the third pivot regarding studies that has tried to investigate the feedback or market reaction to CSR, Adeyanju (2012) discovered a significant relationship between CSR and societal growth. In other words these highlight the important role of CSR in societal progressiveness specifically environmental and economic growth, Hadjikhani et al. (2016) declare that investment in social issues like education, environmental problems and communities aided the firm's entry and increase its market share Baker (2010) found that CSR is how companies manage the business processes to produce an overall positive impact on society,

Companies' size could be related with the level of social connection, according to Smith (1991) discovered that heavy manufacturing companies which operate with smelting and chemical production are usually more closely interested for its environmental than other companies which operated in other industries, the main reason is based on huge companies are supposed to be more dangerous to its environment, Besides that, he find a strong relation between firm size and the amount of social responsibility disclosure (Tilt, 1994). This indicates that the size has a clear effect on the heavy industries, such as; oil and gas industry, they are more likely to implement activities related to social responsibility.

Although, there is no effects of the size are clear in industries such as retailing firms' or financial services, while Joyner, Payne and Raiborn (2002) found in his study that smaller companies has better understand for corporate social responsibility than larger companies, also they discovered the main internal and external factors that 
would cause inconsistency in the ethical behaviour is CSR, the opposite view found by, Thompson and Smith (1991) whom stated that small businesses have not been encouraged to ignore social activities but instead of that they focus on how avoiding irresponsible behaviour.

Also CSR influenced by the ethics of the firm, ethical incentive can guide the firm to perform the correct thing without any external stress from governmental or any other part. Joyner, Payne, and Raiborn (2002) who stated that several factors that legitimize their place and one of the most factors is society, but Ogrizek (2001) find that business with a good attitude in corporate responsibility will get high positive reputation, also business are starting to recognize market benefits and competitive advantages for companies who put into their consideration the comprehensive CSR policy.

Previous studies convey evidence that public associations increase companies' ability in understanding what their environment need and what the best ways to satisfy it, monitor such issue facilitates thinking about what makes a good for the company, in addition to that the standards and expectations which it is extracted will provide companies with high strategy to increase its chance to be more acceptable. which in turn enable companies to play a important role in the raising of CSR standards and in assessment private sector performance, it become clear that all prior studies used quantitative method. Some studies have examined the effect of CSR in developed countries and all of these studies used the quantities methodology while this study will applied anew methodology qualitative method.

\subsection{Definition of Corporate Social Responsibility}

Until yet there is no specific or comprehensive definition for social responsibility, because each company has different thinking, vision, goals, background, and interest. In the literature there are several definitions concerning social responsibility, depending on their views or opinion regarding responsibility.

Many researchers (Ioannis, 2011; Joyner, Payne, \& Raiborn, 2002; Coldwell, 2000; Grunig, 1979) define CSR as includes five important issues, starting with economic, legal, ethical activities and any activities aims to improving the society. Corporate social responsibility is also the continuing commitment of companies towards its environment with ethical elements (Richardson et al., 1999). Companies have responsible for improving the country economic by improving the quality of life for whole workforce (Abbott \& Monsen, 1979). While Odetayo et al. (2014) stated that corporate social responsibility are activates executed by firms to its society, such as environment protection, social facilities such as health and safety, applied in a moral method and always aims to satisfy the external environment needs and wants, and balancing between shareholders' stakeholders interests, also CSR implies how companies can carry out its operation ethically and contribute to improving the quality of life for in their society. There is no doubt that social responsibility becoming an important concept to attain companies goals, this concept has the ability to make a change in accounting thought if used effectively, through increase companies acceptable which in turn increase profit, because they contribute to change the accounting environment.

Currently, many researchers have focused on strategic implications of corporate social responsibility (CSR), in line with (McWilliams \& Siegel, 2001) who identify CSR as "actions that appear as good practice, socially acceptable, consistent with the interests of the firm and in line with law" while Roland (2010) define nine factors that affect on CSR as follow: governance and leadership, company policy, management competencies, monitoring, assessment and reporting competencies, stakeholder meeting, partnership with employees, government support, beneficiation practices and funding, and all of these factors effect on companies success.

\section{Research Methodology}

This section explain the methods the researcher will used in order to gain the best solution for study questions, and to get a clear description for the phenomena and deeper understanding for corporate responsibility impact, semi-structure interview will applied, the researcher has a good knowledge with qualitative approach, starting from contact with the sample, formulate interview questions, data collection, data classifying, and how measure, understand the themes and data analysis and interpretation (Kanakriyah, 2013). in any type of research to ensure the success of the study, the researcher is responsible for determining the required data, and then determine the appropriate means for data collection, and how to classify these data carefully, and choose the best method for the analysis process so as to ensure access to the best results, and then comes the most important issue is how you can assemble ideas and infer the most important explanation for the study problem (Saunders, 2007; Kanakriyah, 2013) this method classified as tired and hard style, but gives more credibility information which help in interpretation stage to provide valuable information.

Chadwick et al. (1984) revealed that no study findings are better than the techniques used to get them, as 
Saunders et al. (2007) detect that qualitative method as mirror reflect perspectives or opinion about any issue, information, attitude and knowledge. The current study aims to test the CSR concept application and how effects on the company's success from users perspectives. In order to measure the companies' success, most studies measure the success in terms of financial factors such as ROA, ROE (Lakshmi Das \& Amalendu Bhunia, 2016; Gbadamosi, 2016), while a company still needs to make earnings to survive, the researcher put ten variables to measure companies' success the dependent variable, profitability, customer satisfaction, employee satisfaction, competitive position, what your customers are saying, efforts to innovate (research and development), leads acquired, client retention, customer conversion, and social media success.

Also stakeholders theory which the study based on it, justify why the researcher applying the research methodology "semi- structure interview method" to get different, valuable information in addition it enable the researcher understand the non-verbal language, to make sure this methodology can provide significant findings from different stakeholders.

We hypothesised that corporate social responsibility has impact on companies' activities, which it can influence on users' perceptions toward companies which in turn can influence on corporate success. To examine the CSR impact on companies success the author used qualitative study to gather users' perceptions toward the importance of CSR on companies success, according to accounting literature Rasoulzadeh (2010), there is no specific criteria to measure the corporate social responsibility (independent variable), also there is no actual explanation or clear guide for the selected items to measure the extent of CSR, so the researcher will use five issues for measuring corporate social responsibility (Dahlsrud 2006), the issues as follow (Table 1).

Table 1. Issues of CSR and related issues source (Dahlsrud, 2006)

\begin{tabular}{cll}
\hline No & Issue (Dimension) & Related issue \\
\hline 1. & The environmental issue & the normal environment \\
2. & The social issue & The connection between business and society \\
3. & The economic issue & Socio-economic or financial aspects, including describing CSR in terms of a business process \\
4. & The stakeholder issue & Stakeholders or stakeholder groups \\
5. & The voluntariness issue & Actions not prescribed by law \\
\hline
\end{tabular}

\subsection{Research Scope}

This study spotlight on a new accounting concept, how social responsibility influence on the firms' success according to users' opinions in Jordan. moreover it tries to discover the issues that support the spread using of social responsibility, to achieve that, the study chooses 14 respondents from seven different groups of accounting information users, because they are suppose to be the core of the study as follow (Creditors, Auditors, Investors, and Financial analysts, Accountants, Academics and Customers) to attain their perceptions, whether they are internal members or from outsiders. The sample include all accounting information users, whether they are supporters or opponents for this concept to guarantee achieve neutrality and objectivity, credibility and comprehensiveness of the study, through the use of semi-structured interview the researcher collect the necessary data to get valuable result within the year 2016, that expected to be appropriate to discovering the impact of CSR implementation on companies' success in Jordan. 


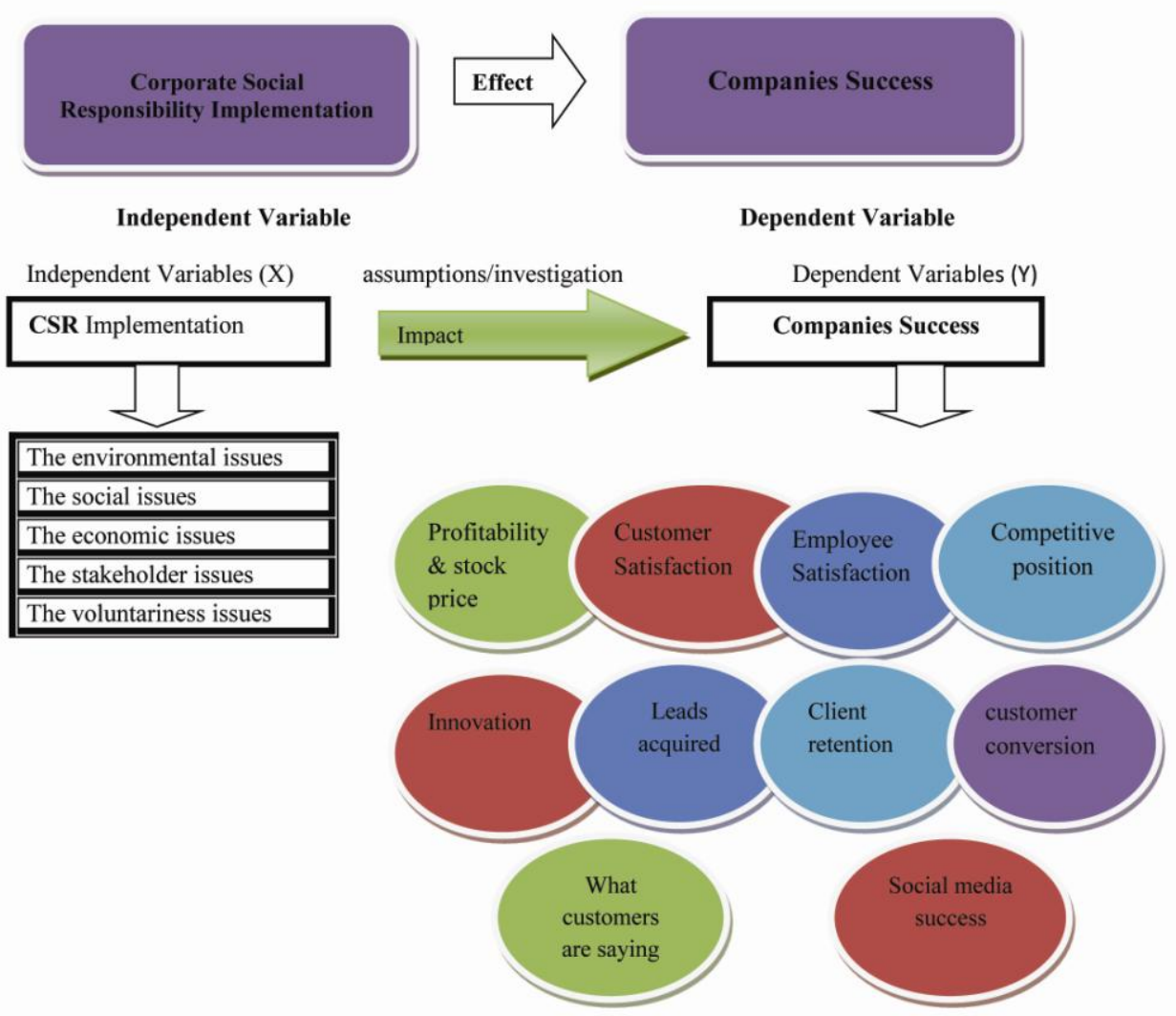

Figure 1. Overview of the nature of the study

The researcher should know how to apply the full variety of data collection techniques (Yin, 2003) Such a complete method of data collection which enable the researcher understood, recognized the perspectives of all interviewees and generate a greatly interactive environment (face to face method). thus, it facilitate to the researcher to pull out reflective and holistic ideas according to the CSR impact on companies success, which rarely used in general study survey.

\section{Analysis, Results and Discussion}

To address the research question, the effect of the CSR factors on company success, the null hypothesis (H0) and alternative hypothesis (H1) were specified as:

H0: The implementation of CSR information doesn't affect on companies' success for internal and external environment.

H1: The implementation of CSR affect on companies' success for internal and external environment, which can express statistically as follows:

$\mathrm{H} 0: \beta=0$ vrs $\mathrm{H} 1: \beta \neq 0$

H0: $\rho=0$ vrs H1: $\rho \neq 0$

The second hypothesis aims to discovering if CSR application effect in users decisions

H0: The CSR application isn't effect the users' decisions

H2: The CSR application effect the users' decisions

$\mathrm{H} 0: \beta=0$ vrs $\mathrm{H} 1: \beta \neq 0$

H0: $\rho=0$ vrs H1: $\rho \neq 0$

This section is concerned with interview process and analysis of the replies, in order to ensure the researcher non-interference in the respondents' answers, the researcher prepared a checklist interview (see appendix 1) that he intended to posed during the interview, so as to ensure that all the interview subjects were covered, and do not 
forget any of the questions, and to achieve neutrality (Kanakriyah, 2013). This required from the interviewer to play a neutral role and never to interrupt respondent's answer, also the researcher should give respondents enough time to express their views to convey their opinions with their language. In other words investigate the opinions of different stakeholder groups about CSR issue in Jordan, (Smith, 2004). The interview was conducted in order to discover stakeholders' perceptions regarding CSR effect on companies' success for seven different groups of accounting information users, two from each group because each group has different needs from others (heterogeneous groups) which will generate different themes,

As well known there are a number of software could be used for qualitative data analysis, for example NUD*IST, NVIVO and ATLAS. NVIVO software prefer to used when the respondents number is more than 30, while in our study the respondents number is fourteen, depending on that, the researcher will used the manual qualitative data analysis, for the reason that it more suitable for the researcher, how has a good knowledge about analyzing data, also the researcher using highlighter pens to make coding between similar ideas of the same question. Another reason for using manual method is the differences between Word and NVIVO document pages which need more effort to make pages computable with word Gibbs (2002) detect the coding process is very important method to categorizing and classifying the data,(similarities and differences themes). Then the researcher start with extracting the most important themes, categorizing the answers, coding the similarities, evaluate data quality, after that begins the stage of interpretation, which need a high degree of coordination between the ideas and opinions and clarify it, to arrive to the best explanation, understanding.

The most important issue in analysis stage is to connected between the data collected and the main goal for the study, or what this study try to answer, In addition, the researcher look for to identify and aware of how all the respondents reply for each question, the degree of similarity or differences, to discover the issues of common interest (themes) between the respondents (Whittemore et al., 2001).

\subsection{Example clarify the Analysis Method (Views on the Nature of the CSR, Purpose and Importance)}

Interview questions were divided into three parts; the first part includes questions 1 and 4 , and aims to discover interviewees' attitudes about the definition, purpose and aims of CSR, and how they understand the concept of CSR? Furthermore, this section aims to explore the rationale for adopting CSR in Jordan through the opinions of the participants. While questions 7 aim to test the influence of CSR on the users' decisions, while questions 2,3,5,6,8,9,10,11 and 12 aims to measure the effect of CSR on the firm's success.

Table 2. Focused coding for Question 1, 4 of section 1(Views on the nature of CSR, purpose and the importance)

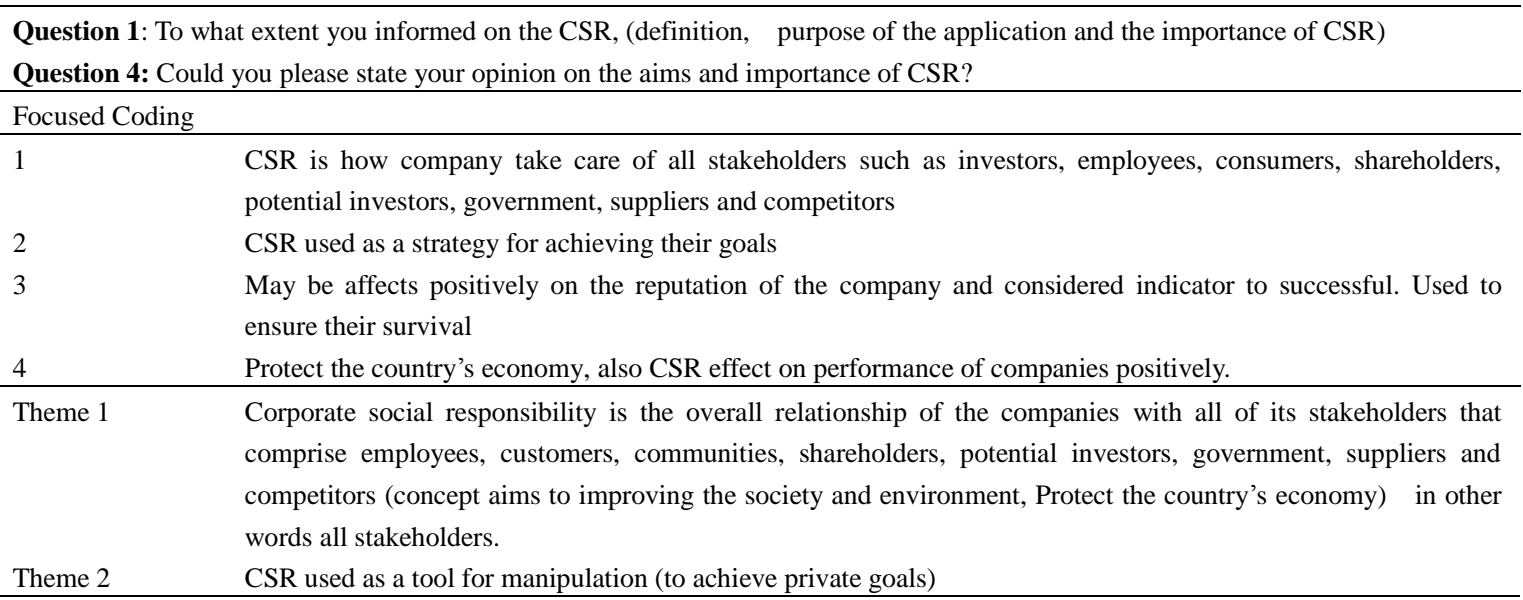

Table 2 illustrates the respondents perspective regarding the definition, goals and importance of 'corporate social responsibility' that can be categorized into four important themes see Table 2: (i) CSR is how company take care of all stakeholders such as investors, employees, consumers, shareholders, potential investors, government, suppliers and competitors (ii) CSR used as a strategy for achieving their goals (iii) May be affects positively on the reputation of the company and considered indicator to successful. Used to ensure their survival (iv) Protect the country's economy, and effect on companies performance positively. These themes lead to a general understood of CSR concept, purposes and importance. According to the themes we are extracted from interview, all respondents have a reasonable information about CSR, but there is still some ambiguity about the objectives 
of social responsibility, they consider CSR as a policy to defending stakeholder' rights, enhancing justice, humanizing the financial reports which will progress companies' reputation, while others such as R13 believe that CSR is a technique used from managers for manipulation.

'I considered CSR concept as tool of manipulation used by companies' managements;, and thus provide incorrect information for users, or the CSR was real, which indicates weak management, prompting investors to fear investing in the shares (stocks) of this company. From my knowledge and experience of the Jordanian market, there was a relationship between the companies that used the CSR and the results of net income of their work; it was found that most companies that were using CSR were making losses, which encourages investors to keep their shares".

R3 have the same opinion about CSR.

"CSR is considered one of the manipulation instruments by the management. Also, management has two important reasons to manipulate earnings. The first one is an external demand to meet earnings forecasts and increase stock price; the second reason represents an internal demand relating to best contracting".

According to the aims of CSR concept the result explain two different theme see Table 4, the first theme consider corporate social responsibility is the overall relationship of the companies with all of its stakeholders that comprise employees, customers, communities, shareholders, potential investors, government, suppliers and competitors (concept aims to improving the society and environment, also to protect the country's economy). All respondent consider CSR as technology used to take responsibility towards stakeholder, social, environment, and economic (R1,R3,R4,R5,R6,R7,R9,R10,R11,R12,R14), with ratio of $86 \%$ percent, while the second view consider CSR as a tool for manipulation, supported from $(\mathrm{R} 3, \mathrm{R} 13)$ with ratio $14 \%$ percent. However some of the interviewees consider CSR as a window for success, consistent with (Servaes \& Tamayo, 2013).

We find that two groups' investors and accountants have a very diverse view on CSR application. Both consider CSR application a technique used by management for illegal purposes; practitioners use it to fool some of the groups who use the financial information, in order to achieve their own goals.

Table 3. Focused coding number 1 for question 1 (CSR definition)

Corporate social responsibility is the overall relationship of the companies with all of its stakeholders that comprise employees, customers, communities, shareholders, potential investors, government, suppliers and competitors.

All Interviewee There is a consensus of all respondents to the social responsibility definition as an modern administrative $\mathrm{R} 1-14 \quad$ concept that will reflect positively on firms

Table 3 shows the answers of the 14 participants who believe that the CSR is popular concept.

Table 4. Focused coding number 1 for question 4 (CSR Aims)

\begin{tabular}{ll}
\hline Could you please state your opinion on the aims and importance of CSR? \\
\hline Theme 1 & Concept aims to improving the society and environment, Protect the country's economy, in other words all stakeholders. \\
Theme 2 & CSR used as a tool for manipulation (to achieve private goals)
\end{tabular}

Table 4 shows the answers of the 14 participants about their opinions regarding question 4 " the aims of applying CSR" two important themes were found, the first theme consider CSR application aims to improving the society and environment, Protect the country's economy, in other words all stakeholders which increase or improve companies success (who support this idea 86\%), while the other theme consider CSR used for personal goals with ratio $(14 \%)$.

Table 5. Focused coding number 1 for hypothesis No.2 (The CSR application isn't effect the users' decisions)

\begin{tabular}{ll}
\hline The CSR application isn't effect the users' decisions Q No.7 \\
\hline 1 & The published of CSR information effect or modify the users decision \\
2 & Any company published CSR information will provide new information which in turn effect on users decisions \\
3 & Effect on decision but sometimes effect negatively \\
Theme & Social responsibility information effect on users decisions \\
\hline
\end{tabular}


According to users' opinion, regarding the second hypothesis the findings indicate that CSR information effect on users' decisions which lead the researcher to refuse the null hypothesis and accept the alternative hypothesis. Because there is a consensus of all respondents see Table 5 that the application of social responsibility activities affect the decision maker regardless of the positive or negative, although most of the respondents said that it has a positive effects on the seminal decisions taken.

For testing the first hypothesis which consider the core of the study "The implementation of CSR information doesn't affect on companies' success for internal and external environment'" the researcher used nine questions to measure the company success, in line with the thought of Sharma et al. (2009) who suggested some variables to measure the company's success, improved profitability, employee morale, market share, stocks price, company reputation, customer satisfaction, legal compliance and societal approval for its existence, applying these improvements depend on using successful corporate social responsibility.

Table 6. Focused coding for hypothesis No.1 (The implementation of CSR information doesn't affect on companies' success for internal and external environment)

\begin{tabular}{|c|c|c|c|c|}
\hline Question & first priority & Second priority & Third priority & $*$ \\
\hline $\begin{array}{l}\text { Question 2: “...CSR information improve the company position } \\
\text { (competitive advantage) improve trust in the company and its managers }\end{array}$ & 9 & 3 & 2 & $64 \%$ \\
\hline $\begin{array}{l}\text { Question 3: "...CSR information effected customer satisfaction and Client } \\
\text { Retention (loyalty) }\end{array}$ & 8 & 4 & 2 & $57 \%$ \\
\hline $\begin{array}{l}\text { Question 5: "...the impact of using CSR information on the employees } \\
\text { satisfaction and improve government relations }\end{array}$ & 11 & 3 & - & $78 \%$ \\
\hline $\begin{array}{l}\text { Question 6: "...the impact of using CSR improve reputation of the } \\
\text { company, enhance image }\end{array}$ & 9 & 1 & 4 & $64 \%$ \\
\hline $\begin{array}{l}\text { Question 8: “...the information regarding CSR effect on companies } \\
\text { market share, stock price, profitability, and create of new } \\
\text { business networks }\end{array}$ & 10 & 3 & 1 & $71 \%$ \\
\hline $\begin{array}{l}\text { Question 9: "...the information that contains CSR activities increase sales } \\
\text { and customer loyalty }\end{array}$ & 12 & 1 & 1 & $85 \%$ \\
\hline $\begin{array}{l}\text { Question 10: ...the CSR information effect on the customer conversion } \\
\text { and social media success }\end{array}$ & 8 & 3 & 1 & $57 \%$ \\
\hline $\begin{array}{l}\text { Question 11:"...the CSR information effect on the competitive position } \\
\text { positively }\end{array}$ & 9 & 3 & 2 & $64 \%$ \\
\hline $\begin{array}{l}\text { Question 12: '...'the customers saying about firms' published CSR } \\
\text { activities is it good }\end{array}$ & 8 & 4 & 2 & $57 \%$ \\
\hline
\end{tabular}

* Number of respondents.

According to users opinion most users believe that CSR application improve the company's success, this is clear from respondents perspectives as presented on Table 6 but the question how the company manage the CSR activities, consistent with Gyves, O'Higgins (2008) who discovered CSR effect positively in financial performance of companies if managed successfully, so companies must put a clear design of strategic CSR which in turn will effects on companies success, consistent with Bhattacharyya et al. (2008). Mattila (2009) finds that companies are investing in different CSR manners; currently the owners and investors are increasingly considering the social and environmental performance of companies beside financial income. Successful companies citizenship which create image better, and good image makes better profit and that means successful companies. According to Rasoulzadeh (2010), the socially responsible that associated with companies stemmed on providing users with all social activities, more than philanthropy and charity, regarding ethics, religion moral, helpful, civilization, thinking and standards which should reflected into companies' strategy.

Figure 2 shows the new model which suggested by the researcher of CSR influences on firms success. The examination results lead to refuse the null hypothesis and accept the alternative hypothesis, because the majority of interviewee beliefs that CSR application is a signal about successful companies and this consequence supported from R8; 
"After applying CSR that's will enhance the reliability, creditability, and present clearer, accurate, information to satisfy the user's needs and wants by humanizing the information content and reporting to help them in their decisions".

From other hand "It will make the reputation of firms affected. According to my knowledge CSR application affected either positively or negatively after the announcement; some users see it as positive while others believe it is as a negative signal, which will effect on any decisions the users are planning to take, in other words that's indicate CSR implementation affect the quality and reliability of the accounting information published. But the question is why successful companies applied "CSR" is it to improve their image. My opinion is CSR application improves the process of decision-making, which reflected on companies' success. Also CSR improve the public image through contributing in social activities, and reduce the government's actions and laws relating to intervene in the affairs of organizations".

Another respondent (R12) agree with the auditors' opinion and suggest that the "CSR concept created to provide a reasonable picture about the role of firms towards its society, and actually I believe that this concept will improve the information published about companies' positions, and companies that applied CSR will differentiate from others by getting competitive advantage'. a lot of of respondents support this vision such as (R2; R8; R9, R10, R12, R5, R11, R7; R6, R4) which enhance the positive role of CSR in improving the firm's success. See R10opinion said "Organization is an integral part of the community, so it has to play a major role in achieving the various society objectives, and that will increase profits in the long term if the organization has adopted a social role".

\section{New model suggestion (developed by the researcher)}
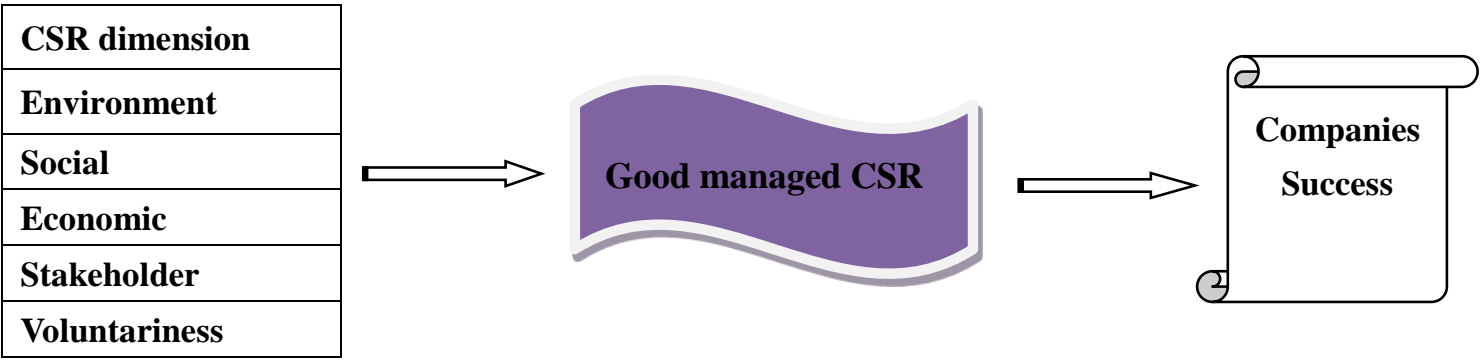

Figure 2. Relationship between dimensions of CSR and companies success

Corporate social responsibility if managed correctly will lead to a business model, taken in our consideration the dimensions of corporate social responsibility (environment, social, economic, stakeholder, and voluntariness) which impact on managed CSR for achieving companies' goals, therefore, CSR effects on companies success (financial performance, market share, and shareholders return).

\section{Conclusions}

This section spotlights the interviewees' beliefs about existing CSR practices in the Jordanian business environment, and the extent to which Jordanian companies are using CSR; in addition, it explores their opinions about the impact of CSR application on companies' success, how the firms apply it; the legal system; the accountability structure; and any elements influencing the CSR application. It also seeks to demonstrate the influence of CSR on companies' success in Jordan. (Kanakriyah, 2013). The interview questions prepared to explain three important issues: First; the definition of 'corporate social responsibility' and its importance, the Second; the characteristic and method used for CSR application of and how effect on users decisions, Third; the impact of applying CSR on the company's success.

The first important results indicate that, all accounting information users have excellent awareness of the CSR concept; objective and goals, the significance of applying CSR. The respondents' opinions discovered important theme explain how CSR affects the companies' reputation and success and enable the users to adjust their decisions.

The second important result explain two different theme see Table 4, the first theme believe corporate social responsibility is the overall relationship of the companies with all of its stakeholders that comprise employees, customers, communities, shareholders, potential investors, government, suppliers and competitors (concept aims to improving the society and environment, also to protect the country's economy). Most respondent consider 
CSR as technology used to take responsibility towards stakeholder, social, environment, and economic while the second view consider CSR as a technique used by the management for manipulation, with ratio $14 \%$ percent.

We find that two groups' investors and accountants have a very diverse vision on CSR application. Both consider CSR application a technique used by management for illegal purposes; practitioners use it to fool some of the groups who use the financial information, in order to achieve their own goals.

while the other groups considered CSR a tool for increasing reliability, More than half of the interviewees (respondents) from all different groups agreed that CSR improved companies profit, also the consequences specified agreement of four groups (Auditors, Creditors, Financial Analysts and Academics) about using CSR improves the companies' reputation which in turn reflected on companies' success, through giving an honest picture of the position of companies, and suggest that the social responsibility of companies seen as a reaction by the effective management of the deteriorating economic conditions in order to save all shareholders and other users of accounting information from the consequences of fraud

The respondents' perspective revealed some factors and problems that affect the use of CSR: effective CSR plan can convey important benefits which include: develop financial performance (increase sales); designing new products and new markets; increase customer loyalty, improve brand image and company reputation; generate new networks; improve employees motivation and skills; improve trust in the company and its managers; improve government relations; reduce regulatory intervention; reduce costs through lower staff turnover; reduce costs through environmental best practice (Rasoulzadeh et al., 2010) which in turn increase companies success.

According to users opinion most users believe that CSR application improve the company's success, also most of the interviewees consider CSR as a window for success, consistent with (Servaes \& Tamayo, 2013). One of the important results of this study, it is recommended that all firms should concern with CSR issues carefully because this activates will affect on companies' success, whether this activities is mandatory or optional and I think this issue need more investigate, through applying a different methods such as questionnaire, or quantitative and qualitative method (Triangulation method).

\section{References}

Abbott, W. F., \& Monsen, R. J. (1979). On the Measurement of Corporate Social Responsibility: Self Reported Disclosures as a Method of Measuring Corporate Social Involvement. Academy of Management Journal, 22(3), 501-515. http://dx.doi.org/10.2307/255740

Abdulrazaq, I., \& Abdu Ja'afaru, B. (2016). The Effect of Corporate Social Responsibility on Firms Financial Performance in Kano Metropolis: A Conceptual Model. International Journal of Management and Commerce Innovations, 4(1), 64-72. Retrieved from http://www.researchpublish.com

Adeleke, C. J. (2014). Corporate social responsibility in the Nigerian banking sector (Doctoral dissertation). Available from ProQuest Digital Dissertations and Theses Database.

Adeneye, B. Y., \& Ahmad, M. (2015). Corporate Social Responsibility \& Company Performance. Journal of Business Studies Quarterly, 7(1), 151-166.

Adeyanju, O. D. (2012). An assessment of the impact of corporate social responsibility on Nigerian society: The examples of banking and communication industries. Universal Journal of Marketing and Business Research, 1(1), 17-43. Retrieved from http://www.universalresearchjournals.org/ujmbr

Alkhalaileh, \& Abu, F. (2016). The Relationship between Corporate Social Responsibility's Disclosure and Financial Performance: An Empirical Study of Jordanian Companies Listed on Amman Stock Exchange. Jordan Journal of Business Administration, 12(2).

AlKhater, K., \& Naser, K. (2003). Users' perceptions of corporate social responsibility and accountability: Evidence from an emerging economy. Managerial Auditing Journal, 18(6/7), 538-548. http://dx.doi.org/10.1108/02686900310482678

Amjad, Joong, W. L., \& Sohee, P. (2016). Corporate social responsibility as a marketing strategy in foreign markets: The case of Korean MNCs in the Chinese electronics market. International Marketing Review, 33(4), 530-554. http://dx.doi.org/10.1108/IMR-03-2014-0104

Baker, M. (2004). Definitions of corporate social responsibility - What is CSR? The World Business Council for Sustainable Development (WBCSD).

Cajias, M., Fuerst, F., \& Bienert, S. (2014). Can investing in corporate social responsibility lower a company's cost of capital? Studies in Economics and Finance, 31(2), 202-222. 
http://dx.doi.org/10.1108/SEF-05-2013-0067

Carlsson, M. G., \& Akerstom, I. K. (2008). The Corporate Social Responsibility and the Theory of the Firm. Retrieved December 20, 2013 from http://www.business.ecu.edu.au/schools/afe/wps/papers/pdfs/wp505.pdf

Carol, A. T. (1994). Corporate Responsibility, Accounting and Accountants. Professionals' Perspectives of Corporate Social 11 Responsibility.

Chadwick, B. A., Bahar, H. M., \& Albrecht, S. L. (1984). Content analysis. In B. A. Chadwick et al. (Eds.), Social Science Research Methods (pp. 239-257). New Jersey: Prentice -Hall

Chin-Huang, L., Ho-Li, Y., \& Dian-Yan, L. (2016). The impact of corporate social responsibility on financial performance: Evidence from business in Taiwan Technology in Society. Technology in Society, 31(1), 56-63.

Chung-Hua, S., \& Yuan, C. (2009). Ambition versus Conscience, Does Corporate Social Responsibility pay off? The Application of Matching Methods. Journal of Business Ethics, 88, 133-153. http://dx.doi.org/10.1007/s10551-008-9826-9

Cochran, P. L., \& Wood, R. A. (1984). Corporate Social Responsibility and Financial Performance. Academy of Management Journal, (27), 42-56. http://dx.doi.org/10.2307/255956

Coldwell, D. A. L. (2000). Perception and Expectations of Corporate Social Responsibility: Theoretical Issues and Empirical Findings. Journal of Business Managerial, 49-54.

Cornell, B., \& Shapiro, A. C. (1987). Corporate stakeholders and corporate finance. Financial Management, 16, 5-14. http://dx.doi.org/10.2307/3665543

Dahlsrud, A. (2006). How Corporate Social Responsibility is Defined: An Analysis of 37 Definitionsî.

Das, L., \& Bhunia, A. (2016). The Impact of CSR on Firms' Financial Performance - A Literature Review. American Journal of Business, Economics and Management, 4(4).

Devinney, T. M., Richard, P. J., Yip, G. S., \& Johnson, G. (2005). Measuring Organizational Performance in Management Research: A Synthesis of Measurement Challenges and Approachesî. Retrieved from http://zip.agsm.edu.au/agsm/web.nsf/AttachmentsBy Title/Orgperf /\$FILE/ORGPERF.pdf

Freeman, R. E., \& Evan, W. M. (1990). Corporate governance: A stakeholder interpretation. The Journal of Behavioral Economics, 19(4), 337-359. http://dx.doi.org/10.1016/0090-5720(90)90022-Y

Freeman, R. E., \& Reed, D. L. (1983). Stockholders and stakeholders: A new perspective on corporate governance. California Management Review, 25(3), 88-106. http://dx.doi.org/10.2307/41165018

Gabriel, J., Navarro, C., \& Mart Y. A. (2009). Linking corporate social responsibility with admiration through organizational outcomes. Social Responsibility Journal, 5(4), 499-511. http://dx.doi.org/10.1108/17471110910995357

Grunig, J. E. (1979). A New Measure of Public Opinions on Corporate Social Responsibility. Academy of Management Journal, 22(4), 738-764. http://dx.doi.org/10.2307/255812

Henri, S., \& Ane, T. (2013). The Impact of Corporate Social Responsibility on Firm Value: The Role of Customer Awareness. Management Science, 59(5), 1045-1061. http://dx.doi.org/10.1287/mnsc.1120.1630

Ioannis, O. (2011). Empirical Investigations of the Relationship between Corporate Social and Financial Performance. Doctora Thesis.

Jensen, M. C., \& Value, M. (n. d.). Stakeholder Theory, and the Corporate Objective Function. Journal of Applied Corporate Finance, 14(3), 8-21.

Joyner, B. E., \& Payne, D. (2002). Evolution and implementation: A study of values, business ethics and corporate social responsibility. Journal of Business Ethics, 41(4), 297-311. http://dx.doi.org/10.1023/A:1021237420663

Joyner, B. E., Payne, D., \& Raibom, C. E. (2002). Building Values, Business Ethics and Corporate Social Responsibility into the Developing Organization. Journal of Developmental Entrepreneurship, 7, 113-131.

Kanakriyah, R. (2013). The effect of Asset Impairment (IAS 36) in Improving the Quality of Accounting Information According to Users' Perspective: Evidence from Jordan. Doctoral Thesis, Durham University, UK.

Kenneth, E. A., Archie, B. C., \& John, D. H. (1985). An Empirical Examination of the Relationship between 
Corporate Social Responsibility and Profitability. The Academy of Management Journal, 28(2), 446-463. http://dx.doi.org/10.2307/256210

Lakshmi, D., \& Amalendu, B. (2016). The Impact of CSR on Firms' Financial Performance. American Journal of Business, Economics and Management, 4(4), 66-74.

McGuire, J. B., Sundgren, A., \& Schneeweis, T. (1988). Corporate social responsibility and firm financial performance. Academy of Management Journal, 31(4), 854-872. http://dx.doi.org/10.2307/256342

Odetayo, T. A., Adeyemi, A., \& Sajuyigbe, A. S. (2016). Impact of Corporate Social Responsibility on Profitability of Nigeria Banks Department of Accountancy. International Journal of Academic Research in Business and Social Sciences, 4(8). http://dx.doi.org/10.6007/IJARBSS/v4-i8/1094

Ogrizek, M. (2002). Forum Paper: The Effect of Corporate Social Responsibility on the Branding of Financial Services. Journal of Financial Services Marketing, 6, 215-228. http://dx.doi.org/10.1057/palgrave.fsm.4770053

Orlitzky, M. (2013). Corporate social responsibility, noise, and stock market volatility. The Academy of Management Perspectives, 27(3), 230-254. http://dx.doi.org/10.5465/amp.2012.0097

Rizk, R., Dixon, R., \& Woodhead, A. (2008). Corporate social and environmental reporting: A survey of disclosure practices in Egypt. Social Responsibility Journal, 4(3), 306-323. http://dx.doi.org/10.1108/17471110810892839

Saunders, M., Lewis, P., \& Thornhill, A. (2007). Research Methods for Business Students.

Sharma, S., Sharma, J., \& Devi, A. (2009). Corporate Social Responsibility: The Key Role of Human Resource Management. Business Intelligence Journal, 2(1), 205-213.

Smith, M. S., \& Alcom, D. S. (1991). Cause Marketing: A New Direction in the Marketing of Corporate Responsibility. Journal of Services Marketing, 6(4), 21-37. http://dx.doi.org/10.1108/07363769110035054

Suwaidan, M., Alomari, A., \& Haddad, R. (2004). Social responsibility disclosure and corporate characteristics: the case of Jordanian industrial companies. International Journal of Accounting, Auditing and Performance Evaluation, 1(4), 432-447. http://dx.doi.org/10.1504/IJAAPE.2004.006355

Thomas, D., \& Lee, E. (1995). The Stakeholder Theory of the Corporation: Concepts, Evidence, and Implications. The Academy of Management Review, 20(1). 65-91. Retrieved from http://www.jstor.org/stable/258887

Thompson, J. K., \& Smith, H. L. (1991). Social responsibility and small business: Suggestions for research. Journal of Small Business Research, 29(1), 30-44.

Waidi, A. G. (2016). Corporate Social Responsibility and Financial Performance of Banks in the United States. Doctoral dissertation, Walden University.

Weshah, S., Dahiyat, A., Awwad, M., \& Hajjat, E. (2012). The Impact of Adopting Corporate Social Responsibility on Corporate Financial Performance: Evidence from Jordanian Banks. Interdisciplinary Journal of Contemporary Research in Business, 4(5), 34-44.

Wu, M., \& Shen, C. (2013). Corporate social responsibility in banking industry: Motives and financial $\begin{array}{lllll}\text { performance. Journal of Banking \& } & \text { Finance, } & 37, & 3529-3547 .\end{array}$ http://dx.doi.org/10.1016/j.jbankfin.2013.04.023

\section{Appendix}

\section{Appendix A. The checklist questions}

\begin{tabular}{ll}
\hline Q. NO & Question \\
\hline Question 1 & To what extent you informed on the CSR concept, (definition, and the purpose of the application)? \\
Question 2 & In your opinion how you see the treatment CSR in the Jordan companies? Is CSR effect on company \\
& stock price, market share (positively or negatively) \\
Question 3 & Is there companies applied CSR in Jordan? Is CSR effected customer satisfaction (improve it) \\
Question 4 & Could you please state your opinion on the aims and importance of CSR? \\
Question 5 & What is the impact of using CSR on the Employees Satisfaction, and Client Retention (loyalty). \\
Question 6 & What is the impact of using CSR on the reputation of the company? \\
Question 7 & The application of the CSR impact in the users' decisions? If yes did you get the influenced by other \\
\hline
\end{tabular}




\begin{tabular}{ll}
\hline Question 8 & companies that already applied CSR? \\
According to your experience do you think that the information regarding CSR effect on companies \\
market share \\
Do you think that information (financial statement) that contains CSR activities is more credible or a \\
tool for increasing manipulation? \\
Question 10 \\
According to your knowledge, do you think that CSR effect on the Customer Conversion and Social \\
Media Success \\
According to your knowledge, do you think that CSR effect on the \\
Competitive Stance for companies, please explain, comment \\
What are the customers saying about firms' published CSR activities? How you see this company
\end{tabular}

Appendix B. Explain the coding for each respondent in the interviews (auditors, creditors, investors, financial analysts, accountants and academics and customers)

\begin{tabular}{ll}
\hline Accountant (1) & $\mathrm{R} 1$ \\
Customer (2) & $\mathrm{R} 2$ \\
Accountant (3) & $\mathrm{R} 3$ \\
Customer (4) & $\mathrm{R} 4$ \\
Auditor (5) & $\mathrm{R} 5$ \\
Auditor (6) & $\mathrm{R} 6$ \\
Financial Analyst (7) & $\mathrm{R} 7$ \\
Financial Analyst (8) & $\mathrm{R} 8$ \\
Academic (9) & $\mathrm{R} 9$ \\
Academic (10) & $\mathrm{R} 10$ \\
Creditor/ Bank (11) & $\mathrm{R} 11$ \\
Creditor/ Bank (12) & $\mathrm{R} 12$ \\
Investor (13) & $\mathrm{R} 13$ \\
Investor (14) & $\mathrm{R} 14$ \\
\hline
\end{tabular}

\section{Copyrights}

Copyright for this article is retained by the author(s), with first publication rights granted to the journal.

This is an open-access article distributed under the terms and conditions of the Creative Commons Attribution license (http://creativecommons.org/licenses/by/4.0/). 